Article

\title{
Studies of the Impact of Hydrogen on the Stability of Gaseous Mixtures of THT
}

\author{
Anna Huszal * (D) and Jacek Jaworski \\ Oil and Gas Institute-National Research Institute, Ul. Lubicz 25a, 31-503 Kraków, Poland; \\ jacek.jaworski@inig.pl \\ * Correspondence: anna.huszal@inig.pl
}

Received: 7 November 2020; Accepted: 3 December 2020; Published: 5 December 2020

check for updates

\begin{abstract}
One of the most important requirements concerning the quality of natural gases, guaranteeing their safe use, involves providing the proper level of their odorization. This allows for the detection of uncontrolled leakages of gases from gas networks, installations and devices. The concentration of an odorant should be adjusted in such a manner that the gas odor in a mixture with air would be noticeable by users (gas receivers). A permanent odor of gas is guaranteed by the stability of the odorant molecule and its resistance to changes in the composition of odorized gases. The article presents the results of experimental research on the impact of a hydrogen additive on the stability of tetrahydrothiophene (THT) mixtures in methane and in natural gas with a hydrogen additive. The objective of the work was to determine the readiness of measurement infrastructures routinely used in monitoring the process of odorizing natural gas for potential changes in its composition. One of the elements of this infrastructure includes the reference mixtures of THT, used to verify the correctness of the readings of measurement devices. The performed experimental tests address possible changes in the composition of gases supplied via a distribution network, resulting from the introduction of hydrogen. The lack of interaction between hydrogen and THT has been verified indirectly by assessing the stability of its mixtures with methane and natural gas containing hydrogen. The results of the presented tests permitted the identification of potential hazards for the safe use of gas from a distribution network, resulting from changes in its composition caused by the addition of hydrogen.
\end{abstract}

Keywords: THT; odorization of gas; safe use of gas; reference gas mixtures; hydrogen; P2G; mixing of hydrogen with natural gas

\section{Introduction}

The rapid depletion of fossil fuels and their negative environmental impact (greenhouse effect, contamination of air with compounds of sulfur and nitrogen, the generation of smog) are reasons behind the increasing share of renewable sources on the energy market. The updated draft of the Energy Policy of Poland until 2040, prepared by the Ministry of Climate and Environment, indicates that this policy will lead to the necessity to invest in sources with lower or even zero emissions [1]. This draft announces the development of the hydrogen market, which will support an increase in the share of renewable energy sources on the country's energy market and assign a new role to the gas sector. However, this should be preceded by the creation of the country's technological and legal background for the development of this area. It should also be pointed out that the Ministry of Climate is preparing the hydrogen strategy of Poland, which, among other things, will contribute to the limitation of the emission of greenhouse gases and other contaminations into the atmosphere in Poland. This points to the predicted increase in interest in hydrogen as an energy carrier. Due to the plans of increasing the use of synthetic gases, biomethane and hydrogen in European gas networks, 
the operators of gas networks must plan for an increase in the transport capacities of gases other than natural via their networks.

This is because the increasing demand for 'clean' and efficient energy results in, among other things, an interest in the utilization of hydrogen for energy purposes [2] as a potential long-term solution to the problem of the growing energy crisis [3-5]. Electrical energy harvested from renewable sources can be stored in the form of hydrogen. To this end, there are considerations for using gas networks as storage of the produced hydrogen $[6,7]$.

At present, there are no legal regulations defining the maximum permissible hydrogen content that can be introduced safely into natural gas networks [8]. Research commenced in this area focuses on determining the most probable and permitted ranges of hydrogen concentrations in the gas network, guaranteeing the safety of the gas system [5,9-13]. It is necessary, on the one hand, to determine the conditions present in a gas network via which hydrogen can be potentially transported (pressure, temperature) and, on the other hand, assess the impact of hydrogen pumped into the networks in an acceptable amount on the quality of fuel gases, devices burning fuel gases or the operation of control and measurement infrastructures [14]. The latter areas especially determine the permitted hydrogen content of natural gas.

For several years, the Oil and Gas Institute-National Research Institute (INIG-PIB) has been researching the possibilities of introducing hydrogen into the gas network. They primarily involve the identification of limitations for this process, resulting from the resistance of individual elements of the gas system to the addition of hydrogen [11]. The research performed so far has focused on: accounts and measurements of fuel gases, the quality of fuel gases [15] and devices burning fuel gases [16]. Research has also continued with respect to the safety of operation and accuracy of the readings of gas meters and gas regulators, and new research areas concerning the impact of hydrogen on the gas network cover issues related to the tightness of mechanical connections of the elements of gas networks and installations, as well as the odorization of fuel gases.

The results of the performed research allowed for the pinpointing of the predicted, not just optimal but primarily permissible, hydrogen content of natural gas, supplied mostly by a gas distribution network. The reduction of the hydrogen content of gas to acceptable values results from the necessity to ensure the safety of the gas network, as well as the users of gas. The maximum levels of hydrogen established so far by the INiG-PIB which can be added 'safely' to methane-rich natural gas are $[10,11]$ :

- $36 \%$ for gas originating from the regasification of LNG and $26 \%$ for gas of group $2 \mathrm{E}-$ due to the quality of gas (retaining legally permitted [17] energy parameters of gas),

- $23 \%$-due to the safety of combustion in end devices,

- $15 \%$-due to the efficiency of combustion in end devices,

- $10 \%$-due to the method of recalculating the compressibility factor,

- $8 \%$-due to the explosion safety of devices working in explosion hazardous areas.

As emphasized by the authors of the abovementioned research $[10,11]$, the produced results are not of a statistical nature, and they do not exhaust the possibilities of further limitations for the permissible safe levels of the hydrogen content of network gas. Forecasts related to further limitations result from the predicted sensitivity of the control and measurement apparatus to hydrogen. Elements of the control and measurement infrastructure of a gas distribution network include analyzers for measuring the concentration of the odorant (in Poland-THT) in gas. Disruptions of their operation or unreliable results of measurements performed by them, caused, e.g., by the increased hydrogen content of gas, will translate directly into the safety of gas users.

\subsection{The Essence of the Odorization of Fuel Gases}

For many years, the odorization of fuel gases has been a common method applied to ensure the safety of their use in practice, due to the fact that it is the odor that is the only feature of gas which can be easily identified in a situation threatening the health and life of its user. Natural gas, 
which lacks the characteristic of an unmistakable scent, forms explosive mixtures in certain proportions with air. This results in the basic idea of the odorization procedure, which is to alert and warn a user not equipped with any measurement devices, and having only their own senses to use, against the impeding danger. This is only possible due to the characteristic odor of properly selected chemical compounds, referred to by the common term odorants or odorizing substances (in the following parts of the article, these names are used interchangeably) [18]. The term 'odorization' describes the entire process of providing fuel gases with a characteristic scent, precisely defined by proper quality standards (e.g., [19-21]). This process begins by introducing an odorizing substance to gas and ends with a complex process of inspecting the level of odorization, including the monitoring of both the odor and the concentration of the odorant in the gas [22].

In the global practice of the gas industry, one of the most important requirements related to the quality of natural gases delivered from a distribution network involves providing a proper level of odorization, enabling the detection of uncontrolled leakages of gases from networks, installations or, finally, from gas devices. Existing European regulations, in this regard, are compatible [22]. Fuel gases distributed via gas networks must be odorized continuously, to such an extent that the gas/air mixture generated in this manner during an uncontrolled leakage of gas would have a distinctly noticeable odor (serving as a warning function against impeding danger). There is a common rule that gas must be detected by any user when its concentration in the air does not exceed $1 / 5$ of the value of concentration corresponding to the lower explosion limit of odorized gas [19,22-24].

Depending on local conditions, the selection of a proper odorant is the responsibility of the company handling the transmission or distribution of gas [25]. An odorant should be characterized by a specific and very intense scent, so that it could be used in very low concentrations. The nature of the scent should be independent of the concentration of gas in the air. Odorants commonly used in Europe include organic sulfur compounds, fulfilling the requirements of ISO 13734 [26]. The ones used most frequently include: tetrahydrothiophene (THT), ethyl mercaptan (EM), tert-butyl mercaptan (TBM), isopropyl mercaptan (IPM), n-propyl mercaptan (NMP) and dimethyl sulfide (DMS). The uses of the individual odorants in European gas odorization systems are presented in Table 1 [8,22]. Tetrahydrothiophene (THT) is the most frequently used odorant among those having sulfur in their compositions in Poland. Countries like the Netherlands, France, Denmark or Poland use it in $100 \%$ of their networks [8].

Table 1. Odorants in European gas odorization systems [22].

\begin{tabular}{ccc}
\hline Country & Odorant & Percentage of Consumption (\%) \\
\hline \multirow{2}{*}{ Austria } & THT & 93 \\
& Sulfur-Free Odorant & 2 \\
& Other odorants & 5 \\
\hline \multirow{2}{*}{ Belgium } & THT & no data ${ }^{1}$ \\
& TBM + IPM + NPM & 100 \\
\hline Switzerland & THT & 10 \\
\multirow{2}{*}{ Czechia } & THT & 89 \\
& TBM + DMS & 1 \\
\hline \multirow{2}{*}{ Germany } & Sulfur-Free Odorant & $55-70$ \\
& THT & $15-19$ \\
& Mercaptan mixtures & 25 \\
Denmark & Sulfur-Free Odorant & 2 \\
\hline
\end{tabular}


Table 1. Cont.

\begin{tabular}{ccc}
\hline Country & Odorant & Percentage of Consumption (\%) \\
\hline Greece & THT & 100 \\
\hline Spain & THT & 100 \\
\hline France & THT & 100 \\
\hline Hungary & THT + TBM & 100 \\
\hline Ireland & TBM + DMS & 100 \\
\hline Italy & THT & 50 \\
\hline The Netherlands & TBM + IPM + NPM & 50 \\
\hline Poland & THT & 100 \\
\hline Portugal & THT & 100 \\
\hline Romania & THT & 100 \\
\hline Slovakia & EM & 59 \\
\cline { 2 - 3 } & THT & 41 \\
\hline Great Britain & TBM + MES & 100 \\
\hline Norway & TBM + DMS & 100 \\
\hline
\end{tabular}

Poland follows the global trends of odorization of natural gases. For years, the Oil and Gas Institute-National Research Institute played a major role in the selection and test of odorants for the gas industry, methods for monitoring gas odorization levels and the ability to improve the efficiency of odorization $[27,28]$. The present article shows the results of INiG-PIB's initial studies related to the impact of hydrogen in a concentration predicted based on its own earlier research $[10,11]$, on the stability of the THT concentration in gaseous mixtures with the addition of hydrogen, taking into account the conditions of the Polish gas network. The results of the research are a basis for forecasting the impact of hydrogen on the quality of odorization of gas using THT. According to the data presented in Table 1, they can also be related to other European countries that use the same odorant.

\subsection{The Impact of Hydrogen on the Odorization of Fuel Gases}

Literature related to the impact of the addition of hydrogen to natural gas on the course of the odorization process is rather poor. The few sources $[29,30]$ indicated the need to perform research in this area without mentioning its expected result. In the 'HYPOS: H2-Netz' project (Hydrogen Power Storage and Solutions) implemented in Germany, related to the production of hydrogen from renewable energy sources, odorization plays a special role as an important safety element of the gas system [31,32]. According to the data of CEN-CENELEC [33], the studies are of a domestic nature, and it is not clear whether they will encompass all types of odorants. On the other hand, it is certain that they are to cover odorization with both sulfur-free odorants, as well as organic sulfur compounds, assuming that the former do not constitute a panacea for the problems identified in the area of odorizing mixtures of natural gas with hydrogen. The experimental field studies which are currently being performed involve the technical possibilities of introducing generated hydrogen into a gas network (a project carried out in a technology park built for the purpose of its execution), taking into account its odorization [32]. Their results will be used by the CEN and CENELEC subcommittees to update standardization documents [33]. On the other hand, the authors of a preliminary expert opinion for the project 'H2-Ready-Assets,' whose goal was to determine the possibility of introducing up to $100 \%$ of hydrogen to the E.ON gas network, claim that the previous experience of the German gas industry 
points to the possibility of odorization using sulfur odorants for mixtures of natural gas with up to $60 \%$ of hydrogen [34]. However, this requires verification in pilot tests.

The report prepared for the British Health and Safety Executive (HSE) [35], based on studies from literature, indicates that the introduction of hydrogen into a gas network will have no impact on the course and effectiveness of the odorization process. This is independent of whether the odorization will affect mixed streams of methane-rich gas and hydrogen or a stream of odorized methane-rich gas with previously odorized hydrogen. Unfortunately, the authors did not specify the percentage of hydrogen in the mixture which was used in this analysis (based on the adopted assumptions, it can be concluded that the permissible level of hydrogen in gas is $20 \%$ ), nor did they reveal its basis in the literature. The predictions refer to odorants in the form of organic sulfur compounds (mercaptans, according to Table 1 above). The assumptions of the HSE's report [35] related to odorization are quoted in a report involving a kickstart project for the development of a countrywide hydrogen strategy for Australia [36]. According to its contents, the literature presented as its basis allows for decisions concerning the lack of contraindications for changing the odorization method and the odorants used (sulfur compounds, including primarily THT).

The report of the Det Norske Veritas (DNV GL, Oslo, Norway) and Germanischer Lloyd (DNV GL, Oslo, Germany) group, published in 2016, presents the results of testing the impact of hydrogen on the intensity of the scent of gas odorized with a mixture of odorants: DMS and TBM [37]. Based on the lack of visible masking of the odor of the mixture of the abovementioned substances via the addition of up to $20 \%$ of hydrogen, it was deemed unnecessary to introduce significant changes in the area of odorization of network gas mixed with hydrogen. However, the authors of the report pointed out that, in spite of the promising results, one cannot rule out the possibility of losing the odorizing substance as a result of a reaction with hydrogen under the conditions of a gas pipeline, which should be assessed in dedicated tests.

According to the analysis presented above, it can be concluded that, in literature, there are currently no reports on the verified possibilities of odorizing mixtures of natural gas with hydrogen without threatening the safety of end users. There is also no information on the performance of proper analytical examinations of the concentration of odorants in such mixtures. This results in a need for experimental verification of, e.g., the magnitude of the measurable impact of hydrogen on the operations of measurement devices used in the odorization of fuel gases, with particular emphasis on process analyzers, which are becoming increasingly popular in the gas industry [38-43]. Additionally, it is extremely important to experimentally verify the possibility of handling the process of odorization through currently-applied methods and with the use of the same odorants. The possibilities of performing such verification include checking the stability of synthetic mixtures of gases containing an addition of hydrogen with the selected odorants. The increase in hydrogen content in natural gas to the tested amounts should not force a change of the odorant that has been used for years and ensures the safety of customers. Since the general public is already used to them, it is advisable to keep using the currently-used gas odorants such as THT.

Tests involving the stability of the composition of tetrahydrothiophene mixtures in gases with an increased hydrogen content (up to $15 \%$ ) were performed in the laboratory of the Department of Gaseous Fuel Odorizing in the Oil and Gas Institute-National Research Institute (INiG-PIB). They constitute the first stage of a whole block of studies currently performed by INiG-PIB in the area of odorization of fuel gases doped with hydrogen.

\section{Materials and Methods}

\subsection{Assumption for the Study}

According to the assumptions of the INiG-PIB, the selection of gas compositions tested for the stability of the THT concentration (indirectly: the stability of odorization by means of THT) was based on its previous own experience [9-11] concerning the permissible hydrogen content of network 
gas. On this basis, the mixtures of methane and hydrogen, as well as methane-rich natural gas and hydrogen, used as reference gases for tests were made up of the following compositions:

- methane with the addition of hydrogen with an amount of $8 \%(V / V)$,

- methane with the addition of hydrogen with an amount of $10 \%(V / V)$,

- methane with the addition of hydrogen with an amount of $15 \%(V / V)$,

- methane-rich natural gas of group 2E with a hydrogen content of $2 \%(V / V)$,

- methane-rich natural gas of group 2E with a hydrogen content of $15 \%(V / V)$.

Higher concentrations of hydrogen in the tested mixtures were not taken into consideration, due to the trend of a gradual decrease in the upper value of its permissible amounts in network gas [9]. In addition, it was assumed that, in particular, higher concentrations of hydrogen in methane will allow for the proper assessment of its potential impact on the level of odorization of gas by means of THT. The evaluation of this impact will be a basis for further 'hydrogen' studies performed with respect to odorization, in terms of determining the magnitude or observing the lack of interference originating from the interaction between the odorant and hydrogen. On the other hand, in the case of natural gas, two extreme levels of the hydrogen content of mixtures from the applied range (i.e., up to $15 \%$ ) were selected for tests. Based on the data from literature [35], it was expected to obtain experimental confirmation of the lack of the impact of hydrogen on the stability of THT molecules in mixtures of methane and natural gas with hydrogen.

According to the research objective, all resulting mixtures of methane and natural gas with hydrogen were odorized using tetrahydrothiophene. The tests were limited to just one odorant, as this was the one used most frequently in European practice and the only one used in Poland. It was assumed that THT concentration should correspond to its average values in the distribution network, i.e., fall within a range of $15.0-30.0 \mathrm{mg} / \mathrm{m}^{3}$ (approx. 4.0-8.0 ppm). The THT concentration calculated in the tested mixtures after the stabilization of their composition, which was considered as a starting point for testing the stability of odorization, ranged from 18.62 to $27.30 \mathrm{mg} / \mathrm{m}^{3}$ (approx. 5.1-7.4 ppm). Table 2 presents the gaseous mixtures used in the tests in the order of examination of the stability of their THT concentrations.

Table 2. List of the compositions of tested gaseous mixtures.

\begin{tabular}{ccc}
\hline No. & Symbol of the Mixture & Composition of the Tested Gaseous Mixture \\
\hline 1 & $\mathrm{M} / \mathrm{H} 8+\mathrm{THT}$ & $92 \%$ Methane $+8 \% \mathrm{H}_{2}(V / V)+5.07 \mathrm{ppm} \mathrm{THT}$ \\
2 & $\mathrm{M} / \mathrm{H} 10+\mathrm{THT}$ & $90 \%$ Methane $+10 \% \mathrm{H}_{2}(V / V)+7.44 \mathrm{ppm} \mathrm{THT}$ \\
3 & $\mathrm{M} / \mathrm{H} 15+\mathrm{THT}$ & $85 \%$ Methane $+15 \% \mathrm{H}_{2}(V / V)+6.70 \mathrm{ppm} \mathrm{THT}$ \\
4 & $2 \mathrm{E} / \mathrm{H} 2+\mathrm{THT}$ & $98 \%$ Natural gas of group $2 \mathrm{E}+2 \% \mathrm{H}_{2}(V / V)+5.23 \mathrm{ppm} \mathrm{THT}$ \\
5 & $2 \mathrm{E} / \mathrm{H} 15+\mathrm{THT}$ & $85 \%$ Natural gas of group $\left.2 \mathrm{E}+15 \% \mathrm{H}_{2} V / V\right)+7.41 \mathrm{ppm} \mathrm{THT}$ \\
\hline
\end{tabular}

The manometric method [44], belonging to static volumetric techniques [45], was selected for the preparation of mixtures. Gaseous mixtures can be prepared using various methods, with the optimized manometric method having been used for many years by the Department of Gaseous Fuel Odorizing in the INiG-PIB to create working reference mixtures of THT for the needs of the calibration of electrochemical analyzers used to measure the concentration of this odorant in the gas network. This method is characterized by a low degree of complexity and satisfying repetitiveness.

The static volumetric method [45] is a technique in which a gaseous mixture is prepared by mixing two or more gases originating from two or more containers of known volume, with all operations being performed under specified conditions of pressure and temperature. The manometric method [44], belonging to this group of techniques, is a static method enabling the preparation of large amounts of gaseous mixtures (including reference gas mixtures) under high pressure. Reference components and dissolving gas are introduced in sequence into a vessel, the volume of which is considered to be constant (ignoring the expansion of the vessel due to pressure changes inside it). The vessel is cleaned 
beforehand, with a vacuum generated inside it. The pressure is checked upon the introduction of each component. The concentration of a given reference component equals the ratio of the pressure increase caused by the introduction of this component to the total pressure of the reference mixture. The conversion of the value of concentration, expressed as a pressure ratio, into a value expressed as a molar ratio is achieved via computational methods. The accuracy of preparing a mixture containing components with a given concentration may vary depending on the type of the generated mixture. For example, a relative accuracy equal to approximately $1 \%$ of concentration, expressed in the form of a pressure ratio or a molar fraction, can be achieved for mixtures of gases whose behavior resembles that of an ideal gas. Since the methods used to calculate the composition of mixtures produced using the manometric technique are not very accurate, the final composition of this mixture (the values of concentrations of the components) is determined using the comparative method [46] or the direct analysis method [47]. Therefore, the odorant content (THT) of gases produced for the needs of testing its stability, containing an increased hydrogen content, was determined by means of the direct analysis method using gas chromatography [48].

\subsection{Gaseous Mixtures for Testing}

The mixtures of gases prepared in the Department of Gaseous Fuel Odorizing in the INiG-PIB were produced from the following components:

- liquid tetrahydrothiophene (THT) (by Chevron Phillips Chemical),

- certified mixtures of hydrogen and methane $(\mathrm{M} / \mathrm{H} 15, \mathrm{M} / \mathrm{H} 10$ and $\mathrm{M} / \mathrm{H} 8$, with respective purities of $15.009 \pm 0.450 \%(\mathrm{~mol} / \mathrm{mol}), 10.002 \pm 0.300 \%(\mathrm{~mol} / \mathrm{mol})$ and $8.013 \pm 0.240 \%(\mathrm{~mol} / \mathrm{mol}))$ (by AirProducts),

- mixtures of natural gas (methane content $>96 \%(\mathrm{~mol} / \mathrm{mol})$ ) and hydrogen (with a purity of 5.0 $(99.999 \%)$ ) (by Air Products), 2E/H2 and 2E/H15, also prepared in the laboratory of the Department of Gaseous Fuel Odorizing in the INiG-PIB.

Before use, the purity of each uncertified component was confirmed chromatographically (GC) in the Department of Gaseous Fuel Odorizing in the INiG-PIB. The 2E/H2 and 2E/H15 mixtures were prepared using the serial dilution method, with their compositions also being checked chromatographically (GC).

The gaseous mixtures of THT were prepared in 10-liter aluminum pressure bottles (manufactured by Luxfer) with Teflon-passivated inner surfaces, eliminating the effect of adsorption of the components of the mixture on the inner walls of the cylinder. The method used to prepare the mixtures is presented in Figure 1. Before filling, each bottle (gas cylinder A) was emptied to a pressure value of approximately $7 \times 10^{-2}$ bar using an oil-free vacuum pump (manufactured by Rocker). Such a degree of cleanliness of the bottles (previously unused) was deemed sufficient for the needs of the performed tests.

The mixtures were prepared using the modified manometric method, developed based on the ISO 6146 quality standard [44]. This method enables the preparation of mixtures under high pressure. The reference components (here: liquid THT) and a complementary gas (here: mixtures of M/H8, $\mathrm{M} / \mathrm{H} 10, \mathrm{M} / \mathrm{H} 15$ or $2 \mathrm{E} / \mathrm{H} 2$ and $2 \mathrm{E} / \mathrm{H} 15$ ) are introduced in sequence into the pressure bottle (gas cylinder A), the volume of which is considered to be constant. The components of the mixture are added by direct dosage of each of them into the cylinder which is being filled. A total of 25.0-35.0 $\mu \mathrm{L}$ of liquid THT was introduced via an injector to each empty bottle with generated vacuum (gas cylinder A-the point of injection is indicated by the symbol $\mathrm{W}$ in the diagram). This was followed by gradual filling of the bottles (by manipulating the valves $Z_{1}$ and $Z_{2}$ ) with a proper compressed gaseous mixture, gradually increasing the pressure of gas in bottle $A$ to reach the assumed maximum value of 125 bar (pressure measurement with an accuracy of \pm 1 bar). Upon filling, the mixture was stirred (a shaker manufactured by GFL) and stabilized at ambient temperature until reaching a stable composition. The strategy of preparation of all mixtures subjected to the tests of stability of the THT concentration is presented in Figure 2. The descriptions included in the figure present the THT content achieved 
after stabilizing the composition of each mixture, adopted as a reference value in stability tests. All the resulting mixtures were stored under stable conditions of pressure and temperature $\left(\mathrm{T}=20 \pm 2{ }^{\circ} \mathrm{C}\right.$, $\mathrm{P}=101.325 \mathrm{kPa}$ ) in order to eliminate the impact of storage conditions on changes in their compositions (eliminating the possibility to condense the components of the mixture).

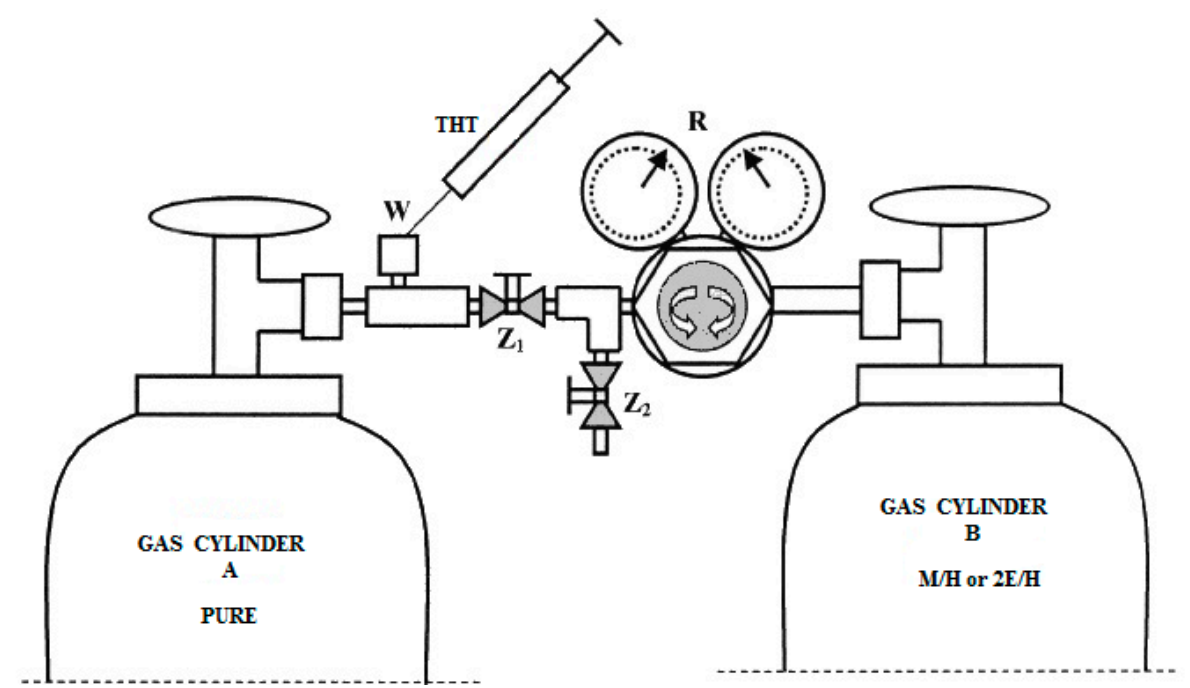

Figure 1. Diagram of connections between bottles: $Z_{1}$-stop valve, $Z_{2}$-relief valve, $W-$ bottle connector with a dispenser, $\mathrm{R}$ - two-stage pressure regulator HP2.

\subsection{Reference Mixtures and a Chromatographic Analysis of the Composition of Mixtures}

The stability of gaseous mixtures of THT containing hydrogen was controlled based on the measurement of THT concentration, performed using the method of gas chromatography with selective detection for sulfur compounds (PFPD). The assessment also involved the appearance of chromatograms derived for these mixtures. The presence of additional peaks in the spectrum could indicate the occurrence of sulfur compounds other than THT, as a consequence of a reaction between hydrogen and the components of the mixtures. The stability of THT concentration over time $\left(x_{n, T H T}\right)$ was adopted as the measure of the stability of gaseous THT mixtures (stability of THT concentration), and thus of the stability of their odorization as well. This should fall within the range defined by the value of THT concentration in the starting point of the tests $\left(x_{0, T H T}\right.$, measurement values specified in Table 3 for a timeframe of 0 days), corrected by the value of expanded uncertainty $\pm U\left(x_{0, T H T}\right)$ (for $\mathrm{k}=2, p=95 \%$ ), i.e., within the following range:

$$
x_{0, T H T}-U\left(x_{0, T H T}\right) \leq x_{n, T H T} \leq x_{0, T H T}+U\left(x_{0, T H T}\right)
$$

where:

$x_{0, T H T}$-initial THT concentration in the gas mixture (attributed value),

$x_{n, T H T}-$ THT concentration in the gas mixture after the lapse of a specified period,

$U\left(x_{0, T H T}\right)$ —expanded measurement uncertainty for the attributed value of THT concentration.

The fulfilment of this condition constitutes the first criterion for the stability of mixtures. The value of statistical parameter $D$, calculated according to ISO 16664, constituted a second parameter (criterion) when assessing the stability of the mixtures [49]. The approval criteria for this parameter are presented in the following section of the article.

The THT content of the prepared gaseous mixtures $\left(x_{n, T H T}\right)$ was determined analytically by comparison with certified reference materials (Primary Standard Gas Mixture (PSM)) for THT according to the ISO 6143 quality standard [46]. The expanded uncertainty of the reference mixture (NPL) equaled $\pm 2.0 \%$ for $\mathrm{k}=2, p=95 \%$. The concentration of THT (expressed as a molar ratio ppm $(\mathrm{mol} / \mathrm{mol}$ ) 
and as mass concentration $\left(\mathrm{mg} / \mathrm{m}^{3}\right) ; \mathrm{T}=20^{\circ} \mathrm{C}$ and $\mathrm{P}=101.325 \mathrm{kPa}$ ) was determined using the gas chromatography method according to the ISO 19739 quality standard [48]. The limit of detection in the method was $0.03 \mathrm{ppm}$ (about $0.1 \mathrm{mg} / \mathrm{m}^{3} ; \mathrm{T}=20^{\circ} \mathrm{C}$ and $\mathrm{P}=101.325 \mathrm{kPa}$ ).

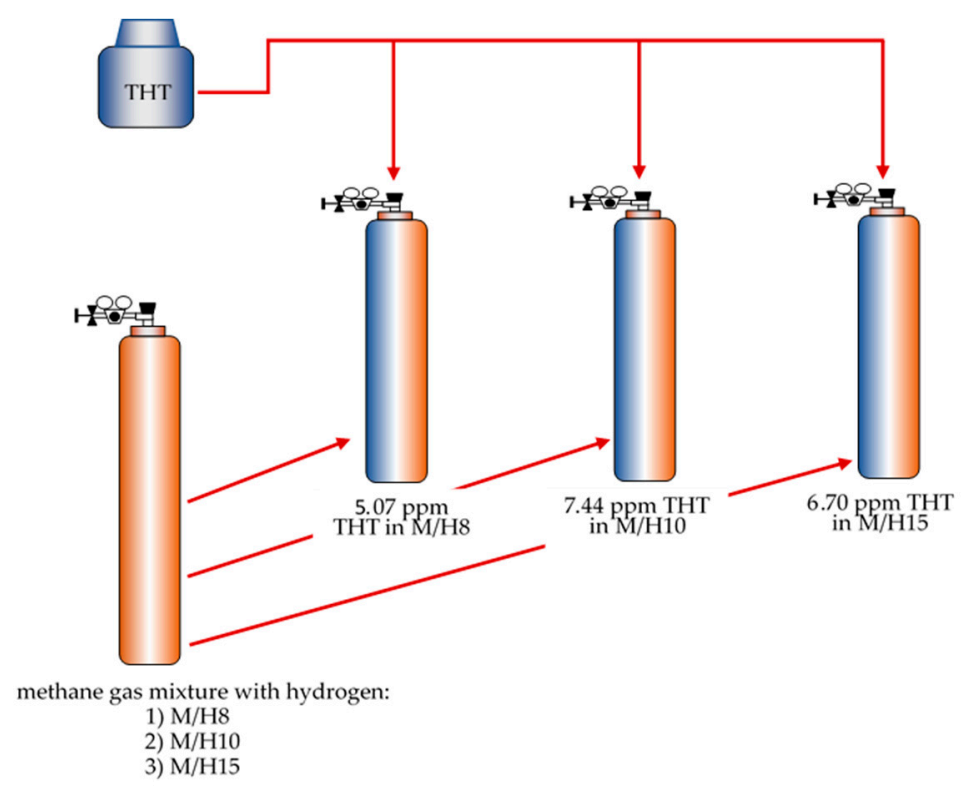

(a)

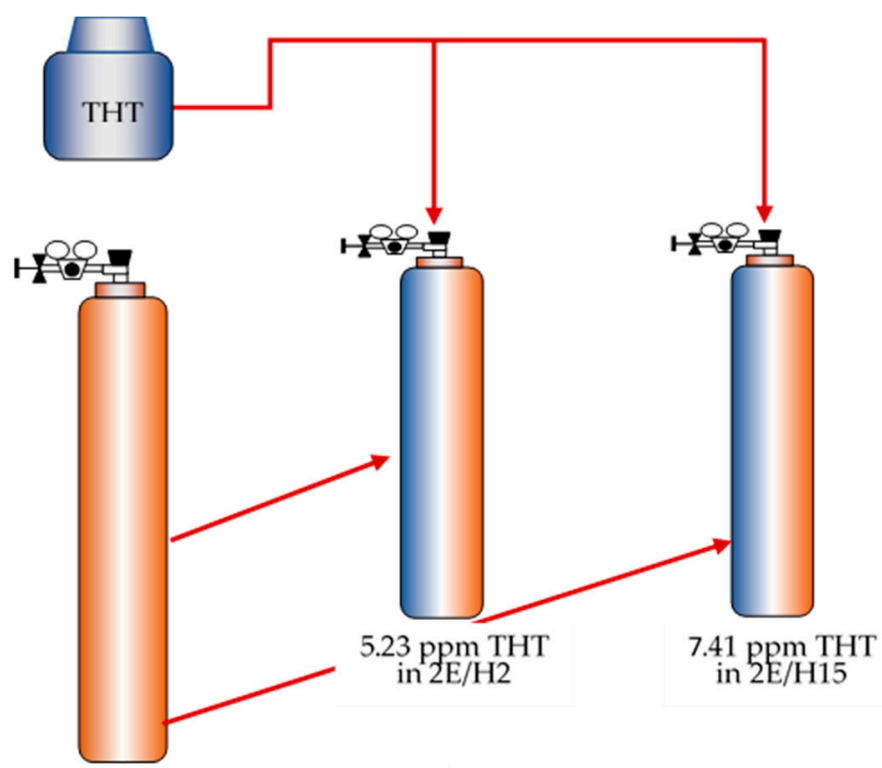

natural gas mixture with hydrogen:

1) $2 \mathrm{E} / \mathrm{H} 2$

(b)

Figure 2. Preparation strategy used to obtain mixtures of tetrahydrothiophene (THT) in methane with the addition of hydrogen (a), and in methane-rich natural gas with the addition of hydrogen (b). 
Table 3. Results of testing the stability of THT concentration in gaseous mixtures of $\mathrm{M} / \mathrm{H}+\mathrm{THT}$ or $2 \mathrm{E} / \mathrm{H}+\mathrm{THT}$.

\begin{tabular}{|c|c|c|c|c|c|}
\hline \multirow{2}{*}{$\begin{array}{l}\text { Storage Time } \\
\text { (Days) }\end{array}$} & \multicolumn{5}{|c|}{ Average Value of THT Concentration $\left(\mathrm{mg} / \mathrm{m}^{3}\right)$} \\
\hline & $\begin{array}{c}\mathrm{M} / \mathrm{H} 8+\mathrm{THT} \\
5.07 \pm 0.31 \mathrm{ppm}\end{array}$ & $\begin{array}{c}\mathrm{M} / \mathrm{H} 10+\mathrm{THT} \\
7.44 \pm 0.46 \mathrm{ppm}\end{array}$ & $\begin{array}{c}\mathrm{M} / \mathrm{H} 15+\mathrm{THT} \\
6.70 \pm 0.41 \mathrm{ppm}\end{array}$ & $\begin{array}{c}2 \mathrm{E} / \mathrm{H} 2+\mathrm{THT} \\
5.23 \pm 0.45 \mathrm{ppm}\end{array}$ & $\begin{array}{l}2 \mathrm{E} / \mathrm{H} 15+\mathrm{THT} \\
7.41 \pm 0.32 \mathrm{ppm}\end{array}$ \\
\hline 0 & $18.62 \pm 1.13$ & $27.30 \pm 1.66$ & $24.60 \pm 1.49$ & $19.20 \pm 1.65$ & $27.20 \pm 1.16$ \\
\hline 7 & $18.93 \pm 1.15$ & $27.44 \pm 1.66$ & $24.70 \pm 1.50$ & $18.60 \pm 1.61$ & $26.60 \pm 1.13$ \\
\hline 14 & $18.36 \pm 1.11$ & $27.46 \pm 1.67$ & $24.27 \pm 1.47$ & $19.95 \pm 1.60$ & $26.32 \pm 1.21$ \\
\hline 21 & $18.57 \pm 1.13$ & $27.71 \pm 1.68$ & $25.03 \pm 1.52$ & $19.27 \pm 1.57$ & $25.85 \pm 1.17$ \\
\hline 28 & $18.51 \pm 1.12$ & $27.53 \pm 1.67$ & $25.30 \pm 1.53$ & $19.35 \pm 1.60$ & $26.33 \pm 1.17$ \\
\hline 35 & $19.30 \pm 1.17$ & $27.63 \pm 1.68$ & $23.68 \pm 1.44$ & $18.99 \pm 1.58$ & $26.09 \pm 1.15$ \\
\hline 42 & $19.50 \pm 1.18$ & $27.13 \pm 1.65$ & $23.90 \pm 1.45$ & $20.34 \pm 1.58$ & $26.10 \pm 1.23$ \\
\hline 49 & $18.89 \pm 1.15$ & $27.12 \pm 1.65$ & $24.39 \pm 1.48$ & $19.30 \pm 1.70$ & $28.00 \pm 1.17$ \\
\hline 56 & $19.14 \pm 1.16$ & $27.57 \pm 1.67$ & $24.38 \pm 1.48$ & $19.01 \pm 1.70$ & $27.98 \pm 1.15$ \\
\hline 63 & $18.17 \pm 1.10$ & $27.15 \pm 1.65$ & $24.31 \pm 1.47$ & $19.26 \pm 1.62$ & $26.78 \pm 1.17$ \\
\hline 70 & $19.52 \pm 1.18$ & $27.51 \pm 1.67$ & $24.58 \pm 1.49$ & $19.15 \pm 1.63$ & $26.88 \pm 1.16$ \\
\hline 77 & $18.95 \pm 1.15$ & $27.36 \pm 1.66$ & $24.55 \pm 1.49$ & $20.18 \pm 1.61$ & $26.54 \pm 1.22$ \\
\hline 84 & $18.59 \pm 1.13$ & $28.00 \pm 1.70$ & $23.65 \pm 1.43$ & $19.66 \pm 1.68$ & $27.76 \pm 1.19$ \\
\hline 91 & $19.09 \pm 1.16$ & $28.06 \pm 1.70$ & $24.81 \pm 1.51$ & $19.64 \pm 1.69$ & $27.84 \pm 1.19$ \\
\hline 98 & $18.65 \pm 1.13$ & $27.68 \pm 1.68$ & $24.26 \pm 1.47$ & $18.45 \pm 1.71$ & $28.12 \pm 1.12$ \\
\hline 105 & $19.13 \pm 1.16$ & $27.98 \pm 1.70$ & $24.80 \pm 1.50$ & $19.85 \pm 1.70$ & $28.09 \pm 1.20$ \\
\hline 112 & $18.79 \pm 1.14$ & $27.77 \pm 1.68$ & $24.12 \pm 1.46$ & $20.28 \pm 1.72$ & $28.40 \pm 1.23$ \\
\hline 119 & $19.11 \pm 1.16$ & $28.01 \pm 1.70$ & $24.68 \pm 1.50$ & $19.34 \pm 1.71$ & $28.26 \pm 1.17$ \\
\hline 126 & $18.63 \pm 1.13$ & $27.63 \pm 1.68$ & $24.80 \pm 1.50$ & $19.30 \pm 1.61$ & $26.53 \pm 1.17$ \\
\hline
\end{tabular}

Reference conditions: $\mathrm{T}=20^{\circ} \mathrm{C}$ and $\mathrm{P}=101.325 \mathrm{kPa}$-for each measuring point. All uncertainties are expanded $(\mathrm{k}=2, p=95 \%)$ uncertainties.

The analyses of the mixtures were performed with the use of a Varian 450 GC chromatograph equipped with a pulsed flame photometric detector PFPD (Varian). A layout of the station used to test the stability of the mixtures is presented in Figure 3. The separation of components was achieved using a capillary column made of molten silica WCot with CP Sil 5CB filling (length $60 \mathrm{~m}$, internal diameter $0.32 \mathrm{~mm}$, filling film thickness $8.00 \mu \mathrm{m}$ ) (manufactured by Varian). The column and the detector were heated to a temperature of $200^{\circ} \mathrm{C}$. The temperature was maintained at a constant level for the entire duration of the analysis. The samples of gaseous mixtures were introduced directly from the pressure bottles to the GC-dispensing speed: approximately $60 \mathrm{~mL} / \mathrm{min}$. A sample chromatogram generated for THT is presented in Figure 4.

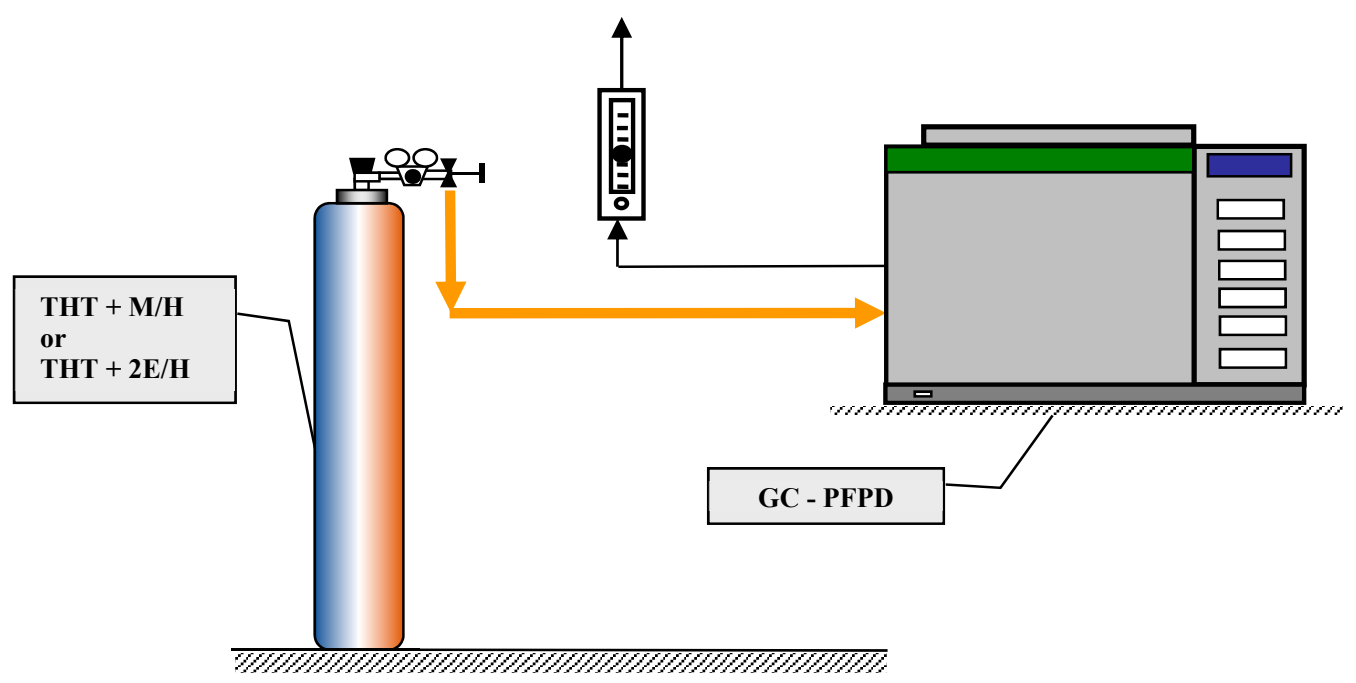

Figure 3. Block diagram of the apparatus in the station examining the composition of gaseous mixtures. 


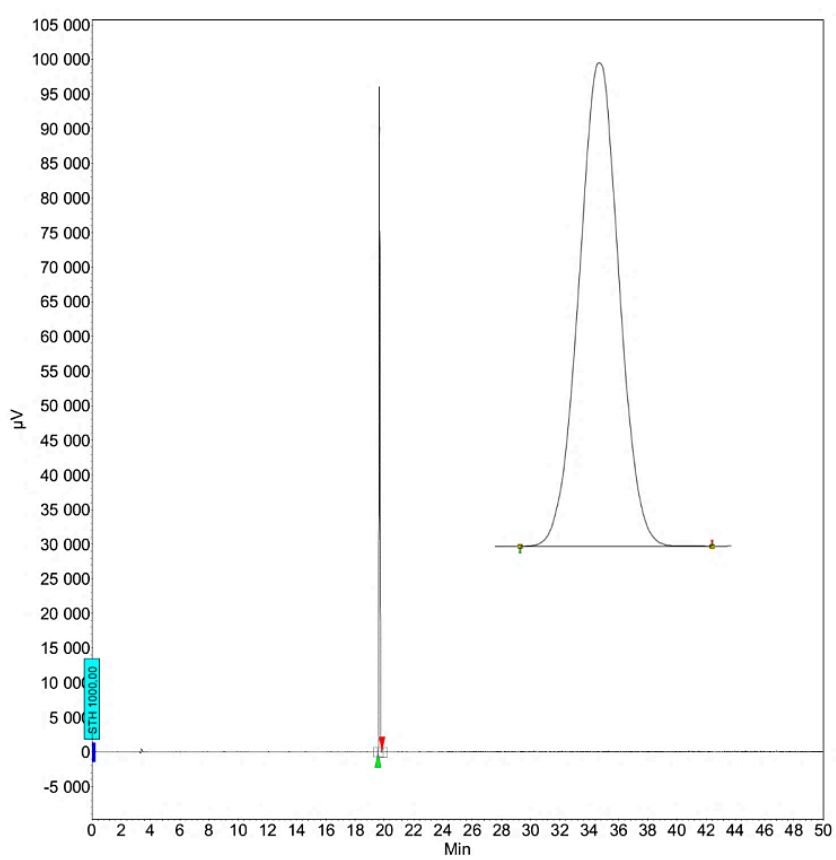

Figure 4. Sample chromatogram generated for a mixture of THT in M/H15 with a THT concentration of $6.70 \mathrm{ppm}\left(x_{T H T}=24.60 \pm 0.50 \mathrm{mg} / \mathrm{m}^{3}, \mathrm{~T}=20^{\circ} \mathrm{C}\right.$ and $\left.\mathrm{P}=101.325 \mathrm{kPa}\right)$.

\section{Results}

The results of testing the stability of THT concentration in the mixtures (as well as the stability of their odorization) with the compositions specified in Table 2 are presented in Table 3 , and graphically in Figures 5 and 6. Each time, the values of expanded uncertainty (for $\mathrm{k}=2, p=95 \%$; presented as error bars on graphs) were specified along with the values of concentration. The value of THT concentration for a timeframe of 0 days $\left(x_{0, T H T}\right)$, determined once the composition of the mixture had stabilized, was considered to be the reference value (interchangeably: the attributed value). For each of the reference values, the THT concentration was expressed as mass concentration $\left(\left(\mathrm{mg} / \mathrm{m}^{3}\right)\right.$ in the contents of the table for the point of 0 days) and a molar fraction (ppm $(\mathrm{mol} / \mathrm{mol})$ in the header of the table), in both cases with a proper attributed value of uncertainty.

The concentrations of THT $\left(x_{n, T H T}\right)$ from the moment of stabilization of their compositions (a point corresponding to a storage time of 0 days) were determined in weekly intervals. The mixtures were stored under laboratory conditions $\left(20 \pm 2{ }^{\circ} \mathrm{C}\right)$. The tests were performed for a period of over 4 months. Each time, which was considered as the result of checking the composition of the mixture, consisted of the average of a minimum of eight repetitions.

The uncertainty of THT concentration was estimated according to ISO 6143 [46] as an expanded uncertainty ( $U$ for $k=2, p=95 \%$ ), based on reference uncertainties and the repetitiveness of GC analyses. The uncertainty budget took into account uncertainty components originating from the uncertainty of secondary standard gas mixtures, the uncertainty of the calibration stage, the uncertainty related to the precision of the method and the uncertainty resulting from the accuracy of the measurement device.

The image of a chromatogram generated each time for the given mixture was also evaluated-as quality control of the stability of the mixtures. 


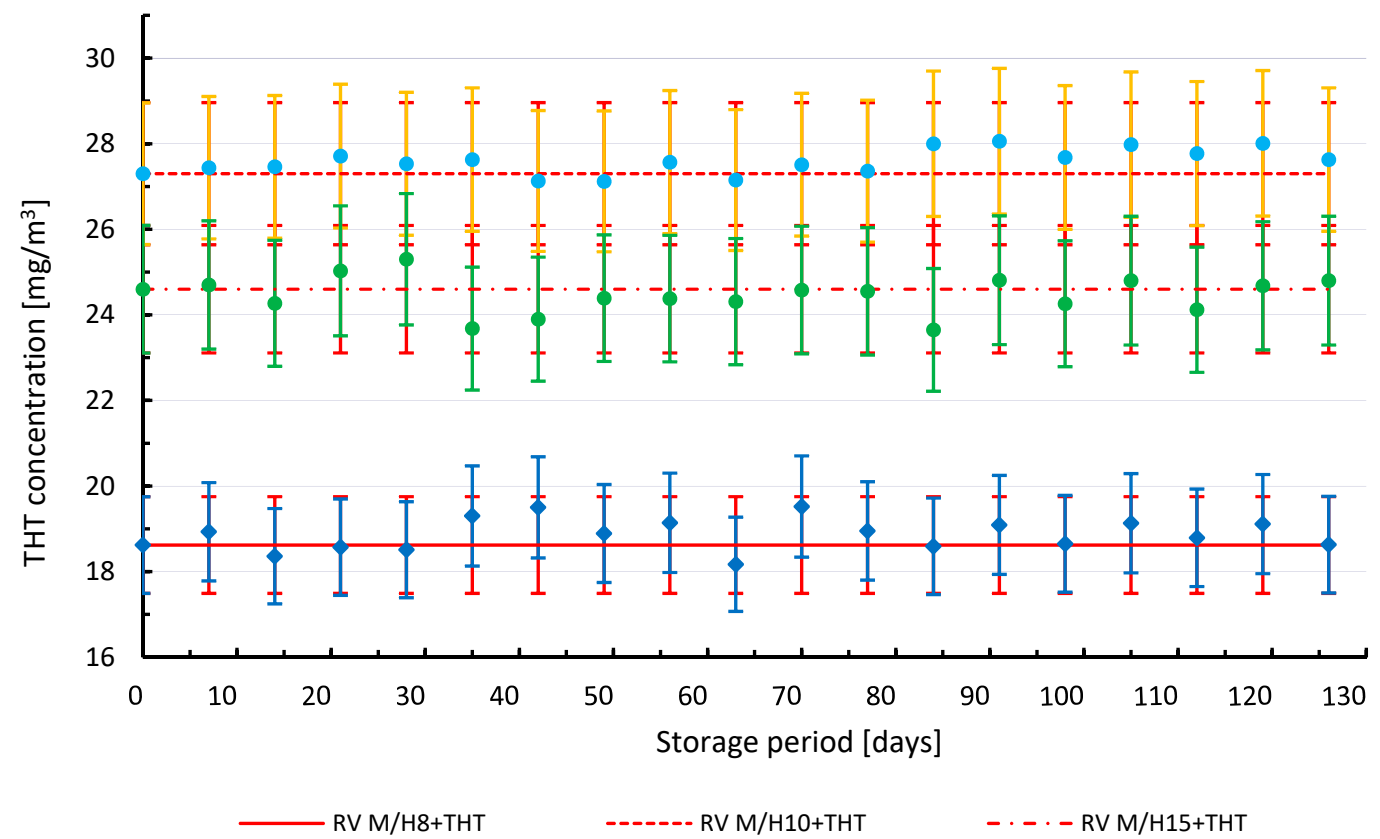

Figure 5. Results of testing the stability of THT concentration in gaseous mixtures of $\mathrm{M} / \mathrm{H}+\mathrm{THT}$ $\left(\mathrm{T}=20^{\circ} \mathrm{C}\right.$ and $\left.\mathrm{P}=101.325 \mathrm{kPa}\right)$.

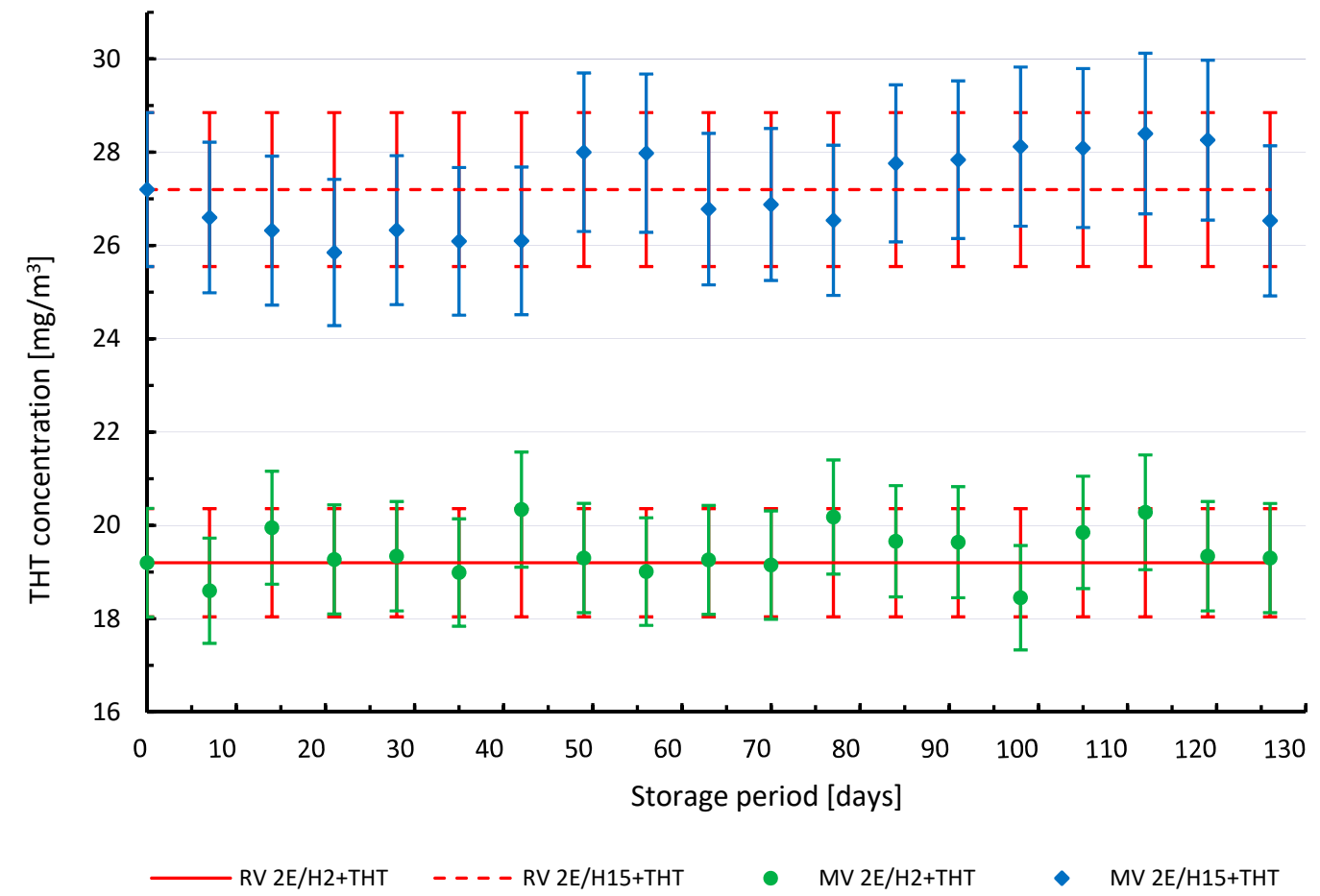

Figure 6. Results of testing the stability of THT concentration in gaseous mixtures of $2 \mathrm{E} / \mathrm{H}+\mathrm{THT}$ $\left(\mathrm{T}=20^{\circ} \mathrm{C}\right.$ and $\left.\mathrm{P}=101.325 \mathrm{kPa}\right)$.

Evaluations of the stability of THT mixtures (THT concentrations in mixtures) were performed on the basis of the statistical parameter $D$ established for each control point (point of monitoring the concentration after a specified time interval). The parameter was determined according to the ISO 16664 quality standard [49] from the following equation:

$$
D=\frac{\left|x_{0, T H T}-x_{n, T H T}\right|}{\sqrt{U^{2}\left(x_{0, T H T}\right)+U^{2}\left(x_{n, T H T}\right)}}
$$


where:

$x_{0, T H T}$-initial THT concentration in the gas mixture (attributed value),

$x_{n, T H T}-$ THT concentration in the gas mixture after the lapse of a specified period,

$U\left(x_{0, T H T}\right)$ —expanded measurement uncertainty for the attributed value of THT concentration,

$U\left(x_{n, T H T}\right)$ - expanded measurement uncertainty for THT concentration after the lapse of a specified period.

The following standardized [47] approval criteria were adopted for the stability of the tested mixtures:

- $\quad D \leq 2$ no major instability,

- $\quad D \geq 2$ major instability.

The resulting values of parameter $D$ of the tested mixtures are listed in Table 4. For comparison, Table 5 presents the values of parameter $D$ for reference mixtures of THT (of various types) in nitrogen $\left(\mathrm{N}_{2}+\mathrm{THT}\right)$, established for reference mixtures stored in the Department of Gaseous Fuel Odorizing in the INiG-PIB under adequate conditions for a period of two years. The tests involved reference mixtures of $\mathrm{N}_{2}+$ THT produced in the Department of Gaseous Fuel Odorizing in the INiG-PIB - working reference gas mixtures (WRM) and certified mixtures—secondary standard gas mixtures (CRM) (symbols used according to ISO 14352 [50]). The stability of the THT mixture in nitrogen is to be considered as a point of reference when assessing the stability of mixtures of THT with various types of gases. Being an inert gas, nitrogen does not react with the THT molecule, which is why changes in the stability of $\mathrm{N}_{2}+$ THT mixtures cannot be the result of chemical reactions between the molecules of both compounds. The high stability of this type of mixtures in the studied time interval indicates that they do not undergo changes of a physical (such as condensation) or chemical type. Therefore, their stability is considered as a point of reference for the stability of mixtures of THT with gases containing the addition of hydrogen. The results of testing the stability of THT mixtures in nitrogen are presented graphically in Figure 7.

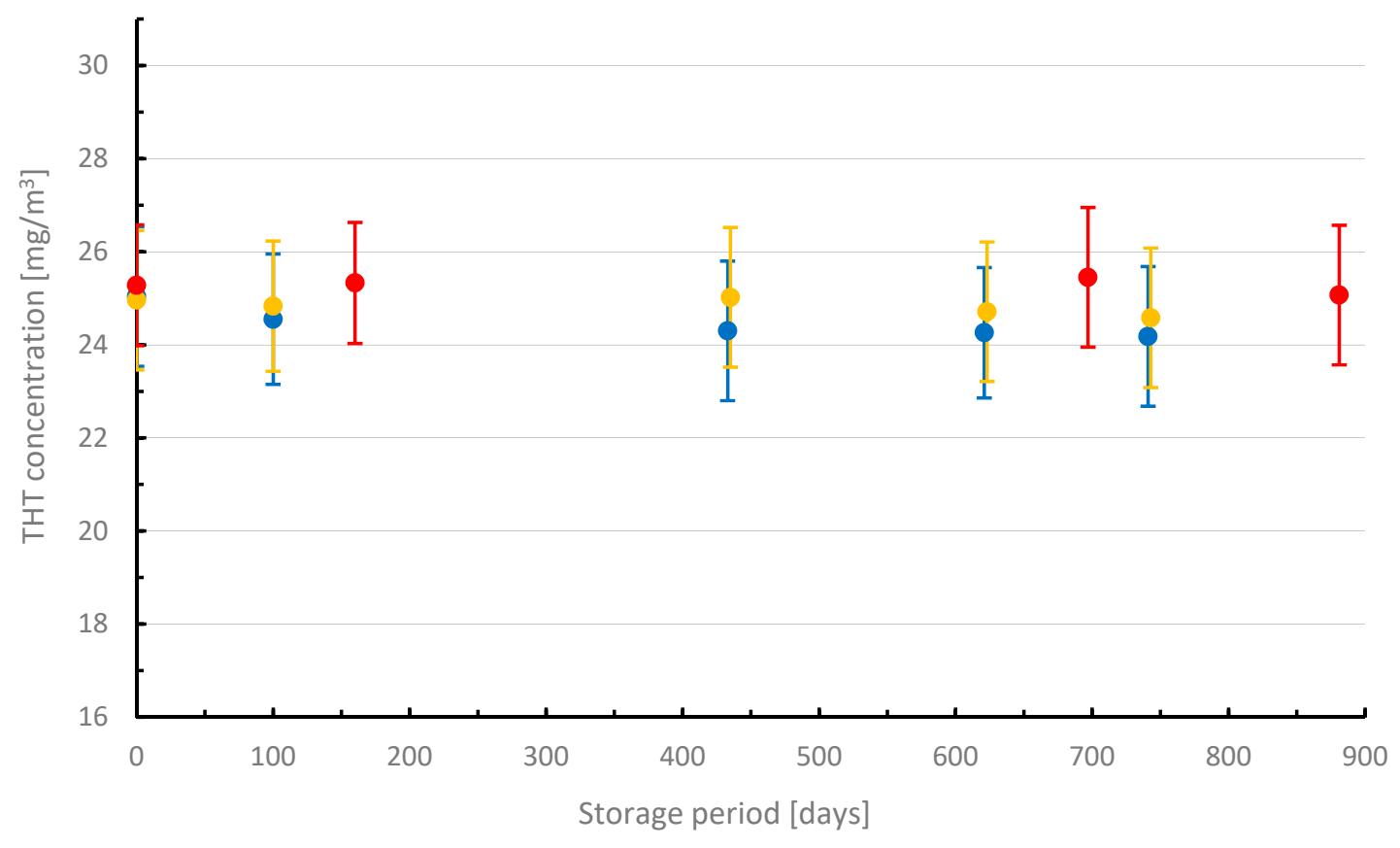

- WRM1 MV N2+THT O WRM2 MV N2+THT $\quad$ CRM MV N2+THT

Figure 7. Results of testing the stability of THT concentration in gaseous mixtures of $\mathrm{N}_{2}+\mathrm{THT}$ $\left(\mathrm{T}=20^{\circ} \mathrm{C}\right.$ and $\left.\mathrm{P}=101.325 \mathrm{kPa}\right)$. 
Table 4. List of the established values of the control parameter $(D)$ for assessing the stability of $\mathrm{M} / \mathrm{H}+\mathrm{THT}$ or $2 \mathrm{E} / \mathrm{H}+\mathrm{THT}$ mixtures.

\begin{tabular}{|c|c|c|c|c|c|}
\hline \multirow{2}{*}{$\begin{array}{l}\text { Storage Time } \\
\text { (Days) }\end{array}$} & \multicolumn{5}{|c|}{ Value of Parameter $D(-)$} \\
\hline & $\begin{array}{c}\mathrm{M} / \mathrm{H} 8+\mathrm{THT} \\
5.07 \pm 0.31 \mathrm{ppm}\end{array}$ & $\begin{array}{c}\mathrm{M} / \mathrm{H} 10+\mathrm{THT} \\
7.44 \pm 0.46 \mathrm{ppm}\end{array}$ & $\begin{array}{c}\mathrm{M} / \mathrm{H} 15+\mathrm{THT} \\
6.70 \pm 0.41 \mathrm{ppm}\end{array}$ & $\begin{array}{c}2 \mathrm{E} / \mathrm{H} 2+\mathrm{THT} \\
5.23 \pm 0.45 \mathrm{ppm}\end{array}$ & $\begin{array}{l}2 \mathrm{E} / \mathrm{H} 15+\mathrm{THT} \\
7.41 \pm 0.32 \mathrm{ppm}\end{array}$ \\
\hline 7 & 0.1925 & 0.0596 & 0.0473 & 0.3700 & 0.2600 \\
\hline 14 & 0.1639 & 0.0681 & 0.1574 & 0.4465 & 0.3833 \\
\hline 21 & 0.0314 & 0.1737 & 0.2020 & 0.0424 & 0.5931 \\
\hline 28 & 0.0691 & 0.0978 & 0.3270 & 0.0847 & 0.3789 \\
\hline 35 & 0.4181 & 0.1401 & 0.4442 & 0.1282 & 0.4855 \\
\hline 42 & 0.5381 & 0.0728 & 0.3364 & 0.6719 & 0.4811 \\
\hline 49 & 0.1678 & 0.0771 & 0.0999 & 0.0606 & 0.3379 \\
\hline 56 & 0.3211 & 0.1147 & 0.1047 & 0.1159 & 0.3295 \\
\hline 63 & 0.2852 & 0.0642 & 0.1382 & 0.0364 & 0.1814 \\
\hline 70 & 0.5500 & 0.0893 & 0.0095 & 0.0304 & 0.1380 \\
\hline 77 & 0.2048 & 0.0256 & 0.0237 & 0.5800 & 0.2863 \\
\hline 84 & 0.0188 & 0.2951 & 0.4589 & 0.2759 & 0.2376 \\
\hline 91 & 0.2908 & 0.3200 & 0.0991 & 0.2641 & 0.2711 \\
\hline 98 & 0.0188 & 0.1611 & 0.1622 & 0.4643 & 0.3877 \\
\hline 105 & 0.3150 & 0.2868 & 0.0944 & 0.3880 & 0.3753 \\
\hline 112 & 0.1060 & 0.1990 & 0.2297 & 0.6375 & 0.5031 \\
\hline 119 & 0.3028 & 0.2992 & 0.0378 & 0.0847 & 0.4455 \\
\hline 126 & 0.0063 & 0.1401 & 0.0944 & 0.0606 & 0.2907 \\
\hline
\end{tabular}

Table 5. List of the established values of the control parameter $(D)$ for assessing the stability of THT mixtures in nitrogen.

\begin{tabular}{|c|c|c|c|c|}
\hline & \multicolumn{4}{|c|}{$\mathrm{N}_{2}+\mathrm{THT}-\mathrm{WRM} 16.89 \pm 0.41 \mathrm{ppm}$ Storage time (days) } \\
\hline & 100 & 433 & 621 & 741 \\
\hline \multirow[t]{3}{*}{ Value of parameter $D(-)$} & 0.2388 & 0.3488 & 0.3801 & 0.4054 \\
\hline & \multicolumn{4}{|c|}{$\mathrm{N}_{2}+\mathrm{THT}-\mathrm{WRM} 26.88 \pm 0.41 \mathrm{ppm}$ Storage time (days) } \\
\hline & 100 & 435 & 623 & 743 \\
\hline \multirow[t]{3}{*}{ Value of parameter $D(-)$} & 0.0634 & 0.0283 & 0.1179 & 0.1791 \\
\hline & \multicolumn{4}{|c|}{$\mathrm{N}_{2}+\mathrm{THT}-\mathrm{CRM} 6.94 \pm 0.36 \mathrm{ppm}$ Storage time (days) } \\
\hline & 160 & 697 & \multicolumn{2}{|c|}{881} \\
\hline Value of parameter $D(-)$ & 0.0272 & 0.0856 & \multicolumn{2}{|c|}{0.1058} \\
\hline
\end{tabular}

Reference conditions: $\mathrm{T}=20^{\circ} \mathrm{C}$ and $\mathrm{P}=101.325 \mathrm{kPa}$.

The headers of Tables 4 and 5 present THT concentrations in the mixtures expressed as molar fractions (ppm (mol/mol)), along with the values of expanded uncertainty (for $\mathrm{k}=2, p=95 \%$ ), constituting attributed values (for mixtures of $\mathrm{M} / \mathrm{H}+\mathrm{THT}$ - the value of THT concentration for a period of 0 days; for mixtures of $\mathrm{N}_{2}+\mathrm{THT}$ - values from the certificate or data sheet). Values expressed in ppm $(\mathrm{mol} / \mathrm{mol})$ correspond to the values of mass concentration $\left(\mathrm{mg} / \mathrm{m}^{3}\right)$ presented in the contents of the table for a period of 0 days.

\section{Discussion}

According to the results presented in Table 3 and in Figures 5 and 6, it should be concluded that THT mixtures in methane containing between $8 \%$ and $15 \%$ of hydrogen $(\mathrm{M} / \mathrm{H}+\mathrm{THT})$ were characterized by a relatively high stability.

The chromatographically measured (GC) values of THT concentration indicate that the THT content varied within the following ranges:

- from $-2.4 \%$ to $5.1 \%$ relative to the value of the initial concentration of THT $\left(x_{0, T H T}\right)$ for a mixture containing $8 \%$ of hydrogen (M/H8 + THT),

- from $-0.7 \%$ to $2.8 \%$ relative to the value of the initial concentration of THT $\left(x_{0, T H T}\right)$ for a mixture containing $10 \%$ of hydrogen $(\mathrm{M} / \mathrm{H} 10+\mathrm{THT})$, 
- from $-3.7 \%$ to $2.8 \%$ relative to the value of the initial concentration of THT $\left(x_{0, T H T}\right)$ for a mixture containing $15 \%$ of hydrogen (M/H15 + THT).

The produced results of measuring THT concentration $\left(x_{n, T H T}\right)$ in methane: hydrogen mixtures in each control point (understood as a point for monitoring concentration after a specified time interval) fall within the approved ranges, i.e., ranges of $\left(x_{0, T H T}-U\left(x_{0, T H T}\right)\right) \leq x_{n, T H T} \leq\left(x_{0, T H T}+U\left(x_{0, T H T}\right)\right)$. This resulted in fulfilling the first criterion of the stability of mixtures. This indicates the high stability of odorant molecules and their resistance to the presence of up to $15 \%$ of hydrogen within the studied time interval (126 days).

The stability of THT concentration in mixtures of $\mathrm{M} / \mathrm{H}+\mathrm{THT}$ is confirmed by the results of the calculated parameter $D$ collected in Table 5 . According to the approval criteria adopted for the stability of THT concentration in the tested mixtures $(D \leq 2)$, based on the results of the control parameter $D$, it can be unambiguously concluded that, in the tested storage period, these mixtures exhibited satisfying stability. Therefore, the second adopted criterion for the stability of mixtures was also fulfilled. At each control point, the mixtures fulfill the conditions of maintaining their stability (constant THT concentration). Such variation does not differ much from the variation of the THT concentration in reference mixtures of this compound with pure nitrogen or methane, as presented in Table 5 and in Figure 7.

A higher variation of the determined concentrations of THT $\left(x_{n, T H T}\right)$ was exhibited by its mixture with natural gas containing $2 \%$ and $15 \%$ of hydrogen $(2 \mathrm{E} / \mathrm{H}+\mathrm{THT})$. The measured THT content changed within the following ranges:

- from $-3.9 \%$ to $6.2 \%$ relative to the value of the initial concentration of THT $\left(x_{0, T H T}\right)$ for a mixture containing $2 \%$ of hydrogen $(2 \mathrm{E} / \mathrm{H} 2+\mathrm{THT})$,

- from $-6.9 \%$ to $4.4 \%$ relative to the value of the initial concentration of THT $\left(x_{0, T H T}\right)$ for a mixture containing $15 \%$ of hydrogen $(2 \mathrm{E} / \mathrm{H} 15+\mathrm{THT})$.

Similar to the case of M/H + THT mixtures, all results of measuring the THT concentration yielded for methane: methane-rich natural gas mixtures $(2 \mathrm{E} / \mathrm{H}+\mathrm{THT})$ in each control point fall within the accepted ranges, i.e., within $\left(x_{0, T H T}-U\left(x_{0, T H T}\right)\right) \leq x_{n, T H T} \leq\left(x_{0, T H T}+U\left(x_{0, T H T}\right)\right)$. This confirms the relatively high stability of odorant molecules and their resistance to the presence of up to $15 \%$ of hydrogen in network gas within the studied time interval (126 days).

In this case, the stability of THT concentration in mixtures of $2 \mathrm{E} / \mathrm{H}+\mathrm{THT}$ is also confirmed by the results of the calculated parameter $D$ collected in Table 5. According to the approval criteria adopted for the stability of THT concentration $(D \leq 2)$, it can be unambiguously concluded that these mixtures exhibited a satisfying stability in the tested storage period. In each control point, the mixtures fulfill the conditions of maintaining stability (constant THT concentration). In this case, the second criterion adopted for the stability of mixtures was also fulfilled.

The chromatogram generated each time for all mixtures did not indicate the presence of sulfur compounds other than THT, which confirmed the purity of the tested mixtures (each time resulting in the quality of the spectrum image presented in Figure 4).

The performed tests, both quantitative (measurements of THT concentration) and qualitative (evaluating the shape of the chromatogram), confirmed the lack of impact of hydrogen on THT molecules present in gas (odorized). The results presented in the article only refer to gaseous mixtures with the addition of hydrogen, characterized by the stability of THT concentration under precisely-defined conditions of pressure and temperature. This provides reasons to predict the stability of this odorant in gas from a gas network in which the concentration of hydrogen will not exceed $15 \%$. Therefore, there is a high probability of being able to perform the odorization of methane-rich gas (2E) with the addition of hydrogen using the previously applied odorant, which is THT. However, the formulation of such an argument requires experimental confirmation taking into account real operating conditions. 


\section{Conclusions}

The tests of the stability of gaseous THT mixtures allowed for assessing the impact of the addition of hydrogen to methane and network gas of group 2E on the variation of its odorization by means of THT, based on the monitoring of the concentration of this compound. The presented results of the tests involve a hydrogen content of up to $15 \%$. They confirm that such a hydrogen content in gas will not interact with THT. This also causes the expected probable lack of a need to change the odorant for mixtures of natural gas with hydrogen.

Such promising results of preliminary tests point to a need to test the long-term stability of THT mixtures, taking into account changes in the parameters of performing the experiment (pressure and temperature).

Based on own experience, it can be concluded that it is highly likely that THT mixtures with the studied compositions will remain stable even for several years, since most of the reactive components begin to exhibit losses immediately after the preparation of the mixture.

The produced results will also directly translate into the interpretation of the results of tests conducted with respect to assessing the operation and the quality of measurement results for devices used in supervising the process of odorization of fuel gases, performed using analytical methods. This is because they permitted the ruling out of any possible interference originating from the interaction of hydrogen with the components of samples of odorized methane:hydrogen and methane-rich natural gas:hydrogen mixtures.

Author Contributions: Conceptualization, A.H. and J.J.; Formal analysis, A.H. and J.J.; Funding acquisition, J.J.; Investigation, A.H.; Methodology, A.H. and J.J.; Supervision, A.H. and J.J.; Validation, A.H. and J.J.; Visualization A.H. and J.J.; Writing — original draft, A.H. and J.J.; Writing—review and editing, A.H. and J.J. All authors have read and agreed to the published version of the manuscript.

Funding: The research received funding as part of the statutory work commissioned by the Ministry of Science and Higher Education; order no. 0088/WN/19, archival number: DK-4100-0088/19 and no. 0089/WN/19, archival number DK-4100-0089/19.

Conflicts of Interest: The authors declare no conflict of interest.

\section{Nomenclature}

$x_{T H T} \quad$ tetrahydrothiophene concentration in gas: $\left(\mathrm{mg} / \mathrm{m}^{3}\right)$ or $(\mathrm{ppm})$

$x_{n, \text { THT }} \quad$ THT concentration in the mixture after the lapse of a specified period, $\left(\mathrm{mg} / \mathrm{m}^{3}\right) \mathrm{or}(\mathrm{ppm})$

$x_{0, T H T} \quad$ THT concentration at the starting point of the tests (here: attributed value), $\left(\mathrm{mg} / \mathrm{m}^{3}\right)$ or $(\mathrm{ppm})$

$D \quad$ statistical parameter for the evaluation of stability, (-)

$U\left(x_{0, T H T}\right) \quad$ uncertainty of attributed concentration, $\left(\mathrm{mg} / \mathrm{m}^{3}\right)$ or $(\mathrm{ppm})$

$U\left(x_{n, T H T}\right) \quad$ uncertainty of concentration of component $x$ after the lapse of a specified period, $\left(\mathrm{mg} / \mathrm{m}^{3}\right)$ or $(\mathrm{ppm})$

\section{Abbreviations}

$\begin{array}{ll}\text { INiG_PIB } & \text { Oil and Gas Institute-National Research Institute } \\ \text { CEN } & \text { European Committee for Standardization } \\ \text { CENELEC } & \text { European Committee for Electrotechnical Standardization } \\ \text { CRM } & \text { Certified Reference Material } \\ \text { DMS } & \text { Dimethyl sulfide } \\ \text { DNV GL } & \text { Det Norske Veritas (Norway) and Germanischer Lloyd (Germany) } \\ \text { 2E } & \text { Natural gas of group E of the second gas (high-methane) described in EN 437 } \\ \text { EM } & \text { Ethyl mercaptan } \\ \text { E.ON } & \text { An international energy supplier based in Essen, Germany } \\ \text { GC } & \text { Gas chromatography } \\ \text { HSE } & \text { Health and Safety Executive } \\ \text { HP } & \text { High pressure }\end{array}$




$\begin{array}{ll}\text { IPM } & \text { Isopropyl mercaptan } \\ \mathrm{M} & \text { Pure methane } \\ \text { 2E/H2 } & \text { 2E natural gas mixture with } 2 \% \text { hydrogen content }(V / V) \\ \text { 2E/H15 } & \text { 2E natural gas mixture with } 15 \% \text { hydrogen content }(V / V) \\ \text { M/H8 } & \text { Methane gas mixture with } 8 \% \text { hydrogen content }(V / V) \\ \text { M/H10 } & \text { Methane gas mixture with } 10 \% \text { hydrogen content }(V / V) \\ \text { M/H15 } & \text { Methane gas mixture with } 15 \% \text { hydrogen content }(V / V) \\ \text { NMP } & \text { n-propyl mercaptan } \\ \text { NPL } & \text { National Physical Laboratory } \\ \text { PFPD } & \text { Pulsed flame photometric detector } \\ \text { PRM } & \text { Primary Reference Material } \\ \text { TBM } & \text { Tert-butyl mercaptan } \\ \text { THT } & \text { Tetrahydrothiophene }\end{array}$

\section{References}

1. Polityka Energetyczna Polski do 2040 r. (PEP2040) Projekt Ministerstwa Środowiska i Klimatu z 2020 r. Streszczenie. Available online: https:/www.gov.pl/web/klimat/projekt-polityki-energetycznej-polski-do2040-r (accessed on 15 October 2020).

2. Hydrogen Europe Vision on the Role of Hydrogen and Gas Infrastructure on the Road Toward a Climate Neutral Economy-A Contribution to the Transition of the Gas Market, Hydrogen Europe Report 2019. Available online: https://hydrogeneurope.eu/news/he-vision-role-hydrogen-and-gas-infrastructure-roadtoward-climate-neutral-economy (accessed on 15 June 2020).

3. Parra, D.; Gillott, M.; Walker, G.S. The role of hydrogen in achieving the decarbonization targets for the UK domestic sector. Int. J. Hydrog. Energy 2014, 39, 4158-4169. [CrossRef]

4. Adolf, J.; Arnold, K.; Balzer, C.H.; Louis, J. Wasserstoff-Energie der Zukunft? Energ. Tagesfr. 2017, 67, 74-77.

5. Isaac, T. HyDeploy: The UK's first hydrogen blending deployment project. Clean Energy 2019, 3, 114-125. [CrossRef]

6. Melaina, M.W.; Penev, M.; Zuboy, J. Hydrogen blending in natural gas pipelines. Handb. Clean Energy Syst. 2015, 1, 1-13. [CrossRef]

7. Ogden, J.; Jaffe, A.M.; Scheitrum, D.; McDonald, Z.; Miller, M. Natural gas as a bridge to hydrogen transportation fuel: Insights from the literature. Energy Policy 2018, 115, 317-329. [CrossRef]

8. EN 16726 European Standard. Quality of Gas. Group H; Technical Committee CEN/TC 408; European Committee for Standardization: Brussels, Belgium, 2016.

9. Jaworski, J.; Kułaga, P.; Blacharski, T. Study of the effect of addition of hydrogen to natural gas on diaphragm gas meters. Energies 2020, 13, 3006. [CrossRef]

10. Jaworski, J.; Dudek, A. Study of the effects of changes in gas composition as well as ambient and gas temperature on errors of indications of thermal gas meters. Energies 2020, 13, 5428. [CrossRef]

11. Jaworski, J.; Kukulska-Zając, E.; Kułaga, P. Wybrane zagadnienia dotyczące wpływu dodatku wodoru do gazu ziemnego na elementy systemu gazowniczego. Nafta-Gaz 2019, 10, 625-632. [CrossRef]

12. Blacharski, T.; Kogut, K.; Szurlej, A. The perspectives for the use of hydrogen for electricity storage considering the foreign experience. E3S Web Conf. 2017, 14, 01045. [CrossRef]

13. Kuczyński, S.; Łaciak, M.; Olijnyk, A.; Szurlej, A.; Włodek, T. Thermodynamic and technical issues of hydrogen and methane-hydrogen mixtures pipeline transmission. Energies 2019, 12, 569. [CrossRef]

14. De Santoli, L.; Paiolo, R.; Basso, G.L. An overview on safety issues related to hydrogen and methane blend applications in domestic and industrial use. Energy Procedia 2017, 126, 297-304. [CrossRef]

15. Schuster, T. Ocena jakości paliw gazowych w kontekście wprowadzania wodoru do sieci gazu ziemnego. GAZ WODA I Tech. Sanit. 2019, 1, 4-8. [CrossRef]

16. Wojtowicz, R. An analysis of the effects of hydrogen addition to natural gas on the work of gas appliances. Nafta-Gaz 2019, 75, 465-473. [CrossRef]

17. Regulation of the Minister of Economy Dated 2 July 2010 on Detailed Conditions for the Operation of a Gas System, (Journal of Laws 2010 no. 133 Item 891, as Amended). Available online: http://prawo.sejm.gov.pl/ isap.nsf/DocDetails.xsp?id=WDU20101330891 (accessed on 15 October 2020). 
18. Fink, J. Odorization. In Petroleum Engineer's Guide to Oil Field Chemicals and Fluids, 2nd ed.; Gulf Professional Publishing (Elsevier): Waltham, MA, USA, 2015.

19. ISO/TR 16922 Technical Report. Natural gas. Odorization. Technical Report. Technical Committee ISO/TC 193; International Organization for Standardization: Geneva, Switzerland, 2013.

20. 49 CFR 192.625 Odorization of Gas, Code of Federal Regulations, Standard in U.S and Canada. 1970. Available online: https://www.govinfo.gov/app/details/CFR-2001-title49-vol3/CFR-2001-title49-vol3-sec192625 (accessed on 15 October 2020).

21. AFG RSDG 10 Rev1 Specifications Relating to Odor of Distributed Gas 2006. Available online: https: //aida.ineris.fr/consultation_document/10271 (accessed on 15 June 2020).

22. Salati, E.; Borghols, W.; Casola, A.; Degroote, Q.; Dehaeseleer, J.; Humhal, F.; Kaesler, H.; Klaas, U.; Louvat, A.; Metz, B.; et al. Odorisation in Europe: The MARCOGAZ Overview. Marcogaz Report 2016, GI-OD-16-06. Available online: https:/www.marcogaz.org/app/download/7928132963/GI-OD-16-06.pdf?t=1541667794 (accessed on 15 June 2020).

23. Butenko, A. Odorization of natural gas versus odorization of biomethane: Does equal legal treatment of biomethane on EU and Dutch national levels translate into the same odorization regime? SSRN Electron. J. 2014. [CrossRef]

24. Deymi-Dashtebayaz, M.; Abadi, R.N.B.; Dehkordi, M.M.; Amini, Z. Experimental and numerical investigation of odorant dispersion in natural-gas pipelines. Eur. Phys. J. Plus 2019, 134, 1. [CrossRef]

25. Pritsching, K. Odorierung, 3rd ed.; Vulkan: Essen, Germany, 2010.

26. ISO 13734 International Standard. Natural Gas. Organic Components Used as Odorants. Requirements and Test Methods. Technical Committee ISO/TC 193; International Organization for Standardization: Geneva, Switzerland, 2013.

27. Kucińska, K.; Pasynkiewicz, J. Możliwości poprawy efektywności nawaniania gazu w warunkach krajowych. Nafta-Gaz 1999, 3, 163-170.

28. Lisman, S.; Huszal, A. Dostosowanie prototypu przystawki odorymetrycznej sprzezonej z chromatografem gazowym do badania zapachowej jakosci gazow. Nafta-Gaz 2015, 3, 190-194.

29. Müller-Syring, G.; Henel, M.; Köppel, W.; Mlaker, H.; Sterner, M.; Höcher, T. Entwicklung von Modularen Konzepten zur Erzeugung, Speicherung und Einspeisung von Wasserstoff und Methan ins Erdgasnetz. Raport DVGW. 2013. Available online: https://www.dvgw.de/medien/dvgw/forschung/berichte/g1_07_10.pdf (accessed on 15 June 2020).

30. Dodds, P.E.; Demoullin, S. Conversion of the UK gas system to transport hydrogen. Int. J. Hydrog. Energy 2013, 38, 7189-7200. [CrossRef]

31. Glas, M. Erfahrungen mit Wasserstoffnetzen: Projekt “HYPOS: H2-Netz" im Chemiepark Bitterfeld-Wolfen geht in Betrieb. Gas Energie 2019, 1, 38-41.

32. Thamm, F. Urbane Energieversorgung mit Wasserstoff Testinfrastruktur in Bitterfeld Wolfen. In Proceedings of the CIO-Campus-Veranstaltung "Speichertechnologien und Wasserstoff-auf dem Weg zur Sektorenkopplung", Stralsund, Germany, 16-17 September 2019.

33. CEN-CENELEC-Sector Forum Energy Management-Working Group Hydrogen-2018 Update Report; Publications Office of the European Union: Luxembourg, 2019; JRC117765. [CrossRef]

34. Fönings, K. Wasserstoff im Erdgasnetz. Nutzung Regenerativer Energiequellen und Wasserstofftechnik 2019. In Proceedings of the 26th Symposium Nutzung Regenerativer Energiequellen und Wasserstofftechnik, Stralsund, Germany, 6-8 November 2019; pp. 40-43.

35. Hodges, J.P.; Geary, W.; Graham, S.; Hooker, P.; Goff, R. RR1047 Injecting Hydrogen into the Gas Network-A Literature Search. Research Report Health and Safety Laboratory. 2015. Available online: https://www.hse. gov.uk/research/rrhtm/rr1047.htm (accessed on 15 June 2020).

36. Hydrogen in the Gas Distribution Networks. A Kickstart Project as an Input into the Development of a National Hydrogen Strategy for Australia. 19184-REP-001 Raport GPA Engineering. 2019. Available online: http://www.coagenergycouncil.gov.au/sites/prod.energycouncil/files/publications/documents/nhshydrogen-in-the-gas-distribution-networks-report-2019_0.pdf (accessed on 15 June 2020).

37. Hydrogen Addition to Natural Gas Feasibility Study. Raport DNV GL nr 1103VHX3-Rep-1, Rev. A. 2016. Available online: https://manualzz.com/doc/37117455/hydrogen-addition-to-natural-gas-feasibility-study (accessed on 15 June 2020).

38. Holewa, J.; Szlęk, M. Ocena jakości gazów palnych. Nafta-Gaz 2013, 6, 450-454. 
39. Wiegleb, G. Gasmesstechnik in Theorie und Praxis; Springer Science and Business Media LLC, Springer Vieweg: Berlin, Germany, 2016.

40. Laszuk, W. Problematyka wyznaczania i aktualizacji obszarów rozliczeniowych ciepła spalania oraz obszarów nawaniania z wykorzystaniem urządzeń do zdalnego pomiaru parametrów jakościowych. Nafta-Gaz 2016, 8, 651-659. [CrossRef]

41. Amiet, F.; Amiet, J.P. How to Analyse H2S, All Mercaptans, THT and Total Sulfur for Monitoring Natural Gas or Fuel Gases in Metering Stations. Available online: http://www.chromatotec.com/IMG/pdf/Chomatotec article_amended_proof2_PIN_OCT_16.pdf (accessed on 15 June 2020).

42. Huszał, A. Nawanianie paliw gazowych gwarancją ich bezpiecznego użytkowania. Nafta-Gaz 2017, 73, 878-886. [CrossRef]

43. Juszczak, M.; Szyłak-Szydłowski, M. Chromatographic examinations in the gas network odourised by tetrahydrothiophene. Ecol. Chem. Eng. S 2019, 26, 265-277. [CrossRef]

44. ISO 6146 International Standard Gas Analysis. Preparation of Calibration Gas. Mixtures. Manometric Method. Technical Committee ISO/TC 158; International Organization for Standardization: Geneva, Switzerland, 1979.

45. ISO 6144 International Standard Gas Analysis. Preparation of Calibration Gas. Mixtures. Static Volumetric Method. Technical Committee ISO/TC 158; International Organization for Standardization: Geneva, Switzerland, 2003.

46. ISO 6143 International Standard. Gas. Analysis. Comparison Methods for Determining and Checking the Composition of Calibration Gas. Mixtures. Technical Committee ISO/TC 158; International Organization for Standardization: Geneva, Switzerland, 2001.

47. Konieczka, P.; Namieśnik, J. Ocena i Kontrola Jakości Wyników Pomiarów Analitycznych; WNT: Warszawa, Poland, 2007.

48. ISO 19739 International Standard Natural Gas Determination of Sulfur Compounds Using Gas. Chromatography. Technical Committee ISO/TC 193/SC 1; International Organization for Standardization: Geneva, Switzerland, 2004.

49. ISO 16664 International Standard Gas Analysis. Handling of Calibration Gases and Gas. Mixtures. Guidelines. Technical Committee ISO/TC 158; International Organization for Standardization: Geneva, Switzerland, 2017.

50. ISO 14532 International Standard Natural Gas Vocabulary. Technical Committee ISO/TC 193/SC 1; International Organization for Standardization: Geneva, Switzerland, 2014.

Publisher's Note: MDPI stays neutral with regard to jurisdictional claims in published maps and institutional affiliations.

(C) 2020 by the authors. Licensee MDPI, Basel, Switzerland. This article is an open access article distributed under the terms and conditions of the Creative Commons Attribution (CC BY) license (http://creativecommons.org/licenses/by/4.0/). 